\title{
Retrosacral Lymph Node
}

National Cancer Institute

\section{Source}

National Cancer Institute. Retrosacral Lymph Node. NCI Thesaurus. Code C77648.

A lymph node located in the retrosacral region. 